\title{
FAIR TRADE : MENUJU SEBUAH SISTEM PERDAGANGAN (BARU) BAGI NEGARA-NEGARA DI DUNIA
}

\author{
Wahid Noor Jayn
}

\begin{abstract}
As one of the ancient practices that are still ongoing to date, trade becomes a thing that goes hand in hand with human civilization. The meeting of interests between the seller and the buyer, the producer and the consumer is absolute by the principle of mutual benefit. Current inter-state trade practices are often considered to be detrimental to the Southern states. Supposedly, modernity and the advancement of science and technology make trade principles run in harmony and balance among stakeholders. Developed countries, geographically located in the Northern region, have reliable human resources. It is also supported by a strong financial and governance system. Nevertheless, Northern countries have limited natural resources. On the other hand, the Southern states are endowed with abundant natural wealth but have limitations in human resources. Essentially these two extremes can harmonize .Developed countries are criticized for playing a dual role in implementing their trade policies. In addressing these issues, Fair Trade as a social movement provides hope for the realization of trade justice and provides assurance for producers who come from developing countries in order to get a decent and sustainable life.
\end{abstract}

Keywords : fair trade, just, sustainable, poverty 


\section{Pendahuluan}

Kesenjangan ekonomi, dewasa ini menjadi 'polaritas' baru dalam relasi antar negara. Persoalan ini berkisar antara hubungan Utara-Selatan, pembangunan di negara dunia ketiga, hingga pembentukan poros-poros ekonomi sebagai bagian dari percepatan pembangunan. Kegiatan perdagangan yang melibatkan aktor-aktor internasional tersebut sudah selayaknya menjadi tempat bertemunya kepentingan para pihak yang terlibat. Namun, celakanya, tidak jarang bahwa kegiatan ini dinilai tidak adil dan merugikan salah satu pihak. Frase "tidak ada pihak yang merasa dirugikan" ini sesungguhnya menjadi asumsi pandangan Suranovic (2000: 284) pada konsep fairness. Menurutnya, prinsip pelaksanaan perdagangan yang adil bisa menjadi multitafsir dan bias karena fairness hanyalah sebuah aturan normatif yang kerap kali diabaikan. Namun demikian, pelaksaanaan prinsipprinsip fair trade berkenaan dengan tentang adil dan keberlanjutan, menjadi poin penting yang akan dibahas di sini.

Berkembangnya ilmu pengetahuan dan teknologi khususnya pasca Perang Dingin turut mempengaruhi pola hubungan antar negara. Dinamika ekonomi dan politik internasional dalam periode tersebut yang bersifat bipolar, seketika memunculkan kekuatan tunggal dalam kontestasi perebutan supremasi global. Selaras dengan hal itu, dapat dipahami bahwa dalam periode pasca Perang Dingin adalah masa di mana isu internasional didominasi oleh motivasi ekonomi. Dalam konteks ini, segala kegiatan yang dilakukan 
oleh hampir seluruh bangsa di dunia adalah untuk menjamin kepentingan ekonominya.

Praktik tradisional untuk pemenuhan kebutuhan pihakpihak yang berkepentingan, yakni perdagangan, menjadi tema yang kerap muncul dalam wacana hubungan internasional. Keruntuhan Uni Soviet dalam mempertahankan struktur ekonomi dan gagalnya memberikan jaminan kesejahteraan bagi masyarakat memberikan wawasan baru bagi masyarakat internasional bahwa prinsip dasar sosial kemasyarakatan, yaitu kebutuhan berinteraksi dan membuka diri adalah hal yang mutlak diperlukan.

Terdapat fenomena menarik terakit gagasan interdependensi dalam konteks perdagangan internasional. Kemampuan negara maju dalam mengolah bahan baku menjadi produk yang bernilai ekonomi tinggi kerap kali mengabaikan aspek-aspek kemanusiaan, seperti upah yang tidak layak bagi para pekerja, isu gender, tenaga kerja dibawah umur dan kemiskinan. Di sisi lain, persoalan sosial di negara berkembang bermuara pada minimnya penghasilan masyarakat. Akibatnya, penyelesaian masalah jangka pendek adalah dengan "memberikan akses bagi para pemodal asing untuk mengembangkan usahanya sebagai upaya memperluas kesempatan kerja masyarakat lokal di sektor industri padat karya". Ironisnya, produk yang dihasilkan oleh para pekerja kadang kala bernilai lebih tinggi dibandingkan dengan upah yang mereka terima (Kit, 2018).

Pada kesempatan lain, para aktivis lingkungan 
mengecam berbagai tindakan para pemilik perusaahaan, terutama perusahaan multinasional yang berbasis di negara berkembang, yang abai terhadap standar etika pada alam, contohnya adalah pertambangan emas dan mineral. Hal ini tentu saja berkaitan dengan kelangsungan hidup para penghuni bumi termasuk manusia di dalamnya. Dalam beberapa tahun terakhir, gerakan-gerakan pro lingkungan gencar mengampanyekan aksi gerakan hijau, yang membawa pesan bahwa keberlanjutan hidup lebih penting daripada sekedar keuntungan finansial (Zampetti, 2006:15). Beruntungnya, motor gerakan ini juga lahir dari para pemangku kepentingan di negara-negara maju.

Persoalan lainnya yakni persoalan aturan ketat lembaga internasional seperti Bank Dunia, dan WTO serta anggapan diskriminatif lembaga tersebut terhadap negara-negara dunia ketiga. Berbagai isu dan persoalan tersebut layak untuk dikaji khususnya dilihat dari perspektif negara-negara berkembang yang mayoritas menggantungkan komoditas nasionalnya pada hasil pertanian. 'Keberpihakan' rejim internasional ini ditenggarai sebagai akar persoalan ketimpangan dan ketidakmerataan kesejahteraan di negara-negara berkembang. Komoditas pertanian yang menjadi ujung tombak perekonomian negara terancam oleh ketiadaan pasar dan beralihnya fungsi lahan. Akibatnya, mereka memilih untuk meninggalkan ladang-ladang dan perkebunannya untuk kemudian beralih menjadi pekerja di sektor industri.

Produk pertanian dari negara Selatan pada umumnya 
telah memenuhi standar pasar dunia dan menjadi komoditi unggulan, misalnya kopi. Akan tetapi, penjualan produk tersebut hampir tidak memberikan dampak signifikan kepada para produsen dan petani yang berhubungan langsung dengan komoditas tersebut. Dalam artikel ini, penulis akan memaparkan bagaimana fair trade sebagai sistem perdagangan yang dianggap (akan) mampu mereduksi berbagai persoalan di negara-negara berkembang, serta prinsip apa saja yang harus dipatuhi oleh setiap negara dalam mewujudkan sistem yang seadil-adilnya.

\section{Perdagangan Internasional}

Bagi ekonom abad ke-18, Adam Smith (1723-1790), kesejahteraan suatu negara tidak hanya diukur dari jumlah uang dan barang berharga (emas dan perak) yang berhasil dikumpulkan negara tersebut, tetapi ditentukan oleh bagaimana aktivitas produksi negara tersebut dikonversikan menjadi pemicu pertumbuhan ekonomi berkesinambungan melalui keterlibatan dalam perdagangan antar negara (Crane et.al, 1991 : 55). Pendapat ini mengisyaratkan bahwa suatu negara yang bercita-cita membangun kesejahteraan melalui pertumbuhan ekonomi berkesinambungan harus terlibat dalam perdagangan internasional. Maka, berbeda dengan para penganut sistem ekonomi merkantilis yang berkecenderungan menutup diri dari perdagangan internasional dengan tujuan untuk melindungi perekonomian dalam negeri, pemikiran liberal klasik yang mendasari prinsip 
kerja sama dan hubungan perdagangan antar negara justru mendorong agar negara-negara saling membuka diri dalam perdagangan dan kerja sama internasional yang akan berujung pada pencapaian kesejahteraan bersama.

\section{Fair Trade}

Perdagangan internasional dapat memiliki efek positif yang signifikan terhadap pertumbuhan dan perkembangan ekonomi. Ada banyak faktor sosial, politik, dan geografis yang menyebabkan Revolusi Industri, tetapi perdagangan Inggris dengan negara tetangga dan koloninya memainkan peran yang menentukan dalam mendorong aktivitas industri baru dan menyebarkan kemakmuran ke negara lain. Sejak lama kotakota di Inggris menjadi pusat perdagangan dunia, mengimpor sejumlah besar makanan dan bahan mentah, dan mengekspor barang-barang manufaktur ke Amerika, Asia, dan Afrika. Selain itu, perdagangan internasional memainkan peran utama dalam industri perkembangan Amerika Utara dan Australia pada abad kesembilan belas, dan ekonomi di kawasan Asia Timur, India dan Cina, dalam pertengahan abad kedua puluh. Hal ini menunjukkan bahwa perdagangan diperlukan untuk pengembangan industri yang berkelanjutan. Namun faktanya itu saja tidaklah cukup (Stiglitz, 2005 : 1112).

Fair trade memilki pengertian sebagai suatu kemitraan perdagangan yang didasarkan pada dialog, transparansi, dan 
penghargaan guna membangun keadilan yang lebih besar dalam perdagangan internasional. Dialog merupakan proses komunikasi antara produsen dan organisasi/pedagang perantara serta (dalam beberapa hal) bersama-sama dengan konsumen menciptakan kesepakatan mengenai pedoman dan kriteria fair trade dan bentuk kerjasamanya. Transparansi ditujukan untuk membangun suatu struktur tata perdagangan yang (lebih) adil. Dengan adanya transparansi, semua pihak yang terlibat bisa mengetahui secara pasti kebutuhan dan harapan masing-masing pihak. Penghargaan bagian dari usaha untuk memanusiakan proses perdagangan dengan cara membangun rantai distribusi sependek mungkin. Fair trade menjadi sebuah gerakan yang mendukung proses pembangunan berkelanjutan dengan menawarkan kondisi perdagangan yang lebih baik, serta memenuhi hak-hak para produsen marjinal dan kaum pekerja terutama di Negara miskin berkembang (World Fair Trade Organization, 2018)

\section{Pembahasan}

Kawasan perdagangan bebas (free trade area) menjadi benchmark hampir di seluruh negara kawasan di dunia. Data dari organisasi perdagangan dunia menyebutkan bahwa hingga tahun 2015/2016 negara-negara berkembang menyumbangkan $42 \%$ bagi pangsa pasar dunia (WTO, 2016). Artinya, perkembangan ekonomi di dunia dapat dikatakan hampir seimbang. Namun, yang menjadi catatan adalah bagaimana pemerataan hasil pembangunan ekonomi tersebut apakah cukup berkeadilan, atau hanya pembangunan semu, 
yang nampak baik jika dilihat dari pertumbuhan makro namun minim dalam pembangunan mikro. Perlu digarisbawahi bahwa kesejahteraan para petani/produsen menjadi fokus dalam fair trade. Bagaimana hal ini dapat memberikan dampak positif dan signifikan kepada para produsen kecil sehingga mampu menaikkan kualitas hidup mereka. Berkenaan dengan hal tersebut, pada prinsipnya perdagangan internasional yang menganut sistem "fair trade" harus telah menerapkan standar-standar yang menjadi prinsip fair trade.

Pada bulan November 2001, menteri perdagangan dari 140 negara berkumpul di Doha, Qatar, untuk membuat terobosan bagi Organisasi Perdagangan Dunia (WTO). Para menteri ini mengumumkan bahwa mereka telah mencapai kesepakatan untuk membicarakan persoalan perdagangan dengan kerangka multilateral yang luas, kemudian dikenal dengan istilah Doha Declaration. Semangat perjanjian baru ini ditanggapi dengan kekhawatiran oleh negara-negara berkembang. Hal ini mengacu pada pengalaman mereka yang kerap kali dirugikan oleh perundingan dagang seperti ini. Mereka meyakini bahwa negara-negara industri besar akan menggunakan kekuatan tawar mereka yang unggul untuk memaksa melalui kesepakatan yang akan merugikan negaranegara berkembang (Stiglitz, 2005 : 2).

Dalam kurun waktu kurang dari dua tahun pasca Doha Declaration, WTO mengadakan pertemuan kembali di Cancun, Mexico untuk menindaklanjuti pertemuan sebelumnya. 
Sayangnya petemuan ini diakhiri dengan hasil nihil. Hal ini menjadi mudah ditebak dikarenakan ada ketidakadilan dalam praktik perdagangan yang dirasakan oleh negara-negara berkembang. Persoalan ketidakadilan didasari oleh ketimpangan antara pendapatan produsen dengan harga produk yang tersebar di pasar. Fair trade menghendaki bahwa produsen berhak mendapatkan pendapatan dan standar hidup yang lebih baik mengingat komoditas yang mereka hasilkan adalah komodi tas yang menjadi primadona bagi pasar dunia.

Filosofi dan strategi yang diususng fair trade dengan tagline "Trade not Aid", yang didukung oleh UNCTAD pada 1968 menjadi alternatif solusi yang bermanfaat dalam jangka panjang dibandingkan dengan sekadar memberikan bantuan (aid). Menjangkau konsumen dengan pesan tentang perlunya reformasi perdagangan menjadi fungsi penting dalam gerakan fair trade (Decarlo, 2007: 74). Kendati demikian, pandangan fair trade sebagai alternatif sistem perdagangan dunia tidak terlepas dari kritikan dan sikap skeptis. Dalam uraian berikutnya, akan dipaparkan sejauh mana fair trade memberikan dampak terhadap para produsen kecil dan eksistensi negara berkembang.

\section{a. Optimisme Fair Trade}

Kemampuan produsen menghasilkan produk-produk berkualitas yang berstandar internasional memerlukan keuletan dan disiplin yang tinggi. Di satu sisi hal ini menjadi sesuatu yang positif karena menjadi pemicu bagi produsen 
kecil untuk meningkatkan kualitasnya. Di sisi lain, tuntutan persaingan global dan kompetisi membuat produsen kecil kesulitan dalam menembus pasar internasional khususnya berkaitan dengan regulasi ketat yang diterapkan negara tujuan ekspor (NTE) maupun organisasi perdagangan dunia (WTO).

Hambatan tarif dan non-tarif ini sesungguhnya telah diatur oleh negara-negara berkepentingan melalui berbagai perjanjian perdagangan. Sayangnya, potensi produsen kecil terhalang oleh pemodal yang menanamkan sahamnya dalam insustri skala besar. Padahal pemodal dapat menjadi 'bapak angkat' bagi para produsen kecil untuk merangsang pertumbuhan ekonomi dan kemandirian masyarakat. Beberapa contoh dari Amerika Latin dan Afrika dapat menggambarkan bagaimana fair trade dijalankan.

Seperti seluruh negara di dunia, negara Chili menghabiskan jutaan dolar per tahun untuk pembelian banyak produk. Menurut hukum positif yang berlaku di Chili serta mengikuti aturan dari Organisasi Perdagangan Dunia hal ini tidak menyalahi aturan karena dalam era modern, penawaran terbuka untuk semua pihak baik perusahaan lokal/nasional maupun perusahaan asing. Akan tetapi, para pengusaha lokal begitu khawatir terhadap serbuan produkproduk China atau Taiwan.

Fundación Solidaridad adalah lembaga sosial yang memiliki misi untuk membantu para produsen kecil, yakni para pengrajin boneka tradisional Chili, guna meningkatkan kualitas hidup mereka. Didirikan pada tahun 1974, mereka 
memberdayakan para pengrajin boneka tradisional yang mayoritas adalah wanita dan berada dalam kondisi yang miskin. Pada mulanya mereka 'memberanikan diri' mengikuti pengadaan barang dari Kementrian Pendidikan setempat. Saat itu mereka bersaing dengan perusahaan- perusahaan multinasional seperti Disney Company, Mattel, Fisher Price dan perusahaan besar lainnya. Di akhir sesi, pada akhirnya mereka memenangkan proyek tersebut dan berhasil meyakinkan pemerintah bahwa produk dan kualitas boneka yang mereka miliki dapat bersaing.

Hanya dalam beberapa tahun, pendapatan mereka naik hingga 40\% karena berhasil meyakinkan pemerintah dalam hal supply, kualitas dan harga yang lebih kompetitif. Lebih dari itu, semangat fair trade yang mereka emban menambah kuat keyakinan lembaga ini bahwa fair trade menjadi jawaban atas ketidakpastian masa depan di tengah kemiskinan yang melanda.

Produk-produk Fundación Solidaridad juga telah menjangkau pasar Eropa dan Amerika melalui Intermón Oxfam, SERRV International, Solidar Monde dan Traidcraft Exchange, juga melalui retail seperti Ten Thousand Villages atau A Greater Gift (sebelumnya SERRV). Masing-masing produk ini biasanya dilengkapi informasi tentang bagaimana produk tersebut dihasilkan dan siapa saja yang terlibat didalamnya. Hal ini dilakukan sebagai upaya menjaga hubungan emosional antara konsumen dan produsen di Chili (Decarlo, 2007: 23-26). Orientasi pasar yang luas dan 
berkelanjutan menjadi keunggulan sistem fair trade yang diyakini mampu bertahan dari krisis dunia (Hudson et. al, $2013: 74)$.

Di bagian dunia lainnya, tepatnya di Ghana terdapat perusahaan coklat The Day Chocolate Company yang memiliki konsep "Cocoa Grower-Business Owner". Pada dasarnya, petani diberikan akses dan keluasan dalam mengelola perusahaannya. Prinsip yang dijalankan oleh Day Chocolate Company dengan melibatkan para petani dalam pengambilan keputusan perusahaan mendapat ganjaran berupa British Government Millennium Award. Perusahaan ini merupakan hasil kolaborasi berbagai pihak: Kuapa Kokoo, the Body Shop, the British Non-Governmental Organization, Twin Trading dan para pendukung lainnya, termasuk the British Department for International Development. Mereka berinisiatif membuat produk coklat khusus berlabel fair trade yang diberi nama Divine (Decarlo, 2007 : 27-30).

Kwabena Ohemeng-Tinyase, direktur pengelola Kuapa Kokoo, adalah pembicara utama pada konferensi Fair Trade Futures yang pertama diadakan di Amerika Serikat pada September 2005. Konferensi ini dihadiri oleh 750 konsumen dan pengusaha dari dua puluh negara yang berbeda. Ohemeng-Tinyase menggambarkan manfaat politik, sosial, dan ekonomi dari fair trade sebagai sesuatu yang luar biasa, terutama karena berhubungan dengan kesempatan yang setara bagi perempuan. Ohemeng-Tinyase juga menggarisbawahi pertambahan nilai dan keterampilan bisnis 
di ranah internal asosiasi (Decarlo, 2007: 28).

Lebih jauh, sedikitnya terdapat tiga manfaat yang dirasakan oleh para produsen kecil yang berada di negaranegara berkembang dengan adanya sistem perdagangan ini. Pertama adalah kesempatan menikmati penghasilan/upah kerja layak karena menciptakan peluang kerja baru yang dapat mengurangi angka kemiskinan. Kedua, harga yang adil dan manfaat jangka panjang berupa investasi di bidang sosial, seperti terbukanya akses pendidikan, kesehatan, ketahanan pangan, serta kemampuan pengelolaan organisasi. Ketiga, pemberdayaan wanita dan terhindarnya anak-anak dari "kewajiban" bekerja serta pemanfaatan sumber daya alam dan lingkungan secara wajar.

Dalam praktiknya, prinsip fair trade mendukung kebijakan dan rencana yang jelas untuk mempromosikan kesetaraan gender yang memastikan bahwa perempuan dan laki-laki memiliki kemampuan untuk mendapatkan akses ke sumber daya yang mereka butuhkan untuk menjadi produktif dan juga kemampuan untuk mempengaruhi kebijakan yang lebih luas, peraturan, dan lingkungan kelembagaan (WFTO, 2018).

Menurut Hudson (2013), seluruh manfaat ini dapat digolongkan menjadi dua kriteria yakni tangible (manfaat yang dapat dirasakan langsung seperti bertambahnya penghasilan petani, terjaminnya akses pasar non-konvesmional, akses pendidikan, kesehatan, sarana publik) dan intangible (bertambahnya wawasan, soft skill petani, kemampuan 
manajerial dan organisasi). Sarah Lyon (2007 : 73) menegaskan bahwa fair trade memegang peranan penting dalam kesetaraan dan keadilan global.

\section{b. Skeptisisme}

Klaim keberhasilan fair trade di sebagian negara berkembang tidak selalu berjalan mulus di sebagian negara berkembang yang berada di kawasan lainnya. Kurangnya informasi dan pengetahuan terhadap konsep dan praktik fair trade menjadi hambatan dan tantangan dalam mengampanyekan gerakan ini menjadi gerakan global. $\mathrm{Hal}$ ini dapat dimaklumi mengingat fair trade, dengan kesepuluh prinsipnya, mempunyai aturan ketat agar manfaatnya dapat dirasakan langsung oleh produsen. Tidak jarang hambatan sosial-budaya menjadi salah satu determinan dalam penetrasi fair trade di beberapa negara. Saya akan sedikit mengulas tentang hambatan sosial budaya terkait dengan prinsip fair trade khususnya yang terjadi di Indonesia.

Kluckhohn dan Strodbeck (1961) dalam Mattulada (1987) dalam Ranjabar (2006) mengidentifikasi bahwa budaya 'santai' di Indonesia merupakan akibat pengaruh alam dan lingkungan sehingga tidak mendorong terwujudnya etos kerja yang menghargai waktu, ketelitian, ketekunan, kesabaran dalam usaha, dan ketabahan dalam mengalami kesulitan. Dampaknya dapat dilihat dari seberapa jauh kreatifitas partisipan wanita yang memiliki peran menonjol dan prestasi gemilang di lingkungan kerja. 
Terlebih masyarakat Indonesia kerap kali hanya memikirkan hari ini saja tanpa memikirkan kehidupan di masa yang akan datang. Dalam lingkungan masyarakat petani dan desa-desa di Indonesia, mereka terlampau sulit untuk memikirkan bagaimana kehidupannya, kepemilikannya dan keadaannya di masa depan. Bahkan tidak jarang mereka tenggelam dalam nostalgia zaman keemasan nenek moyang. Ironisnya, tanggapan seperti ini juga terjadi di perkotaan, instansi pemerintahan, pegawai dan pelaku bisnis sekalipun.

Selain masih menganut paham patriarki, secara umum masyarakat Indonesia juga cenderung tetap mempertahankan nilai budaya feodal, yakni mentalitas priyayi dan orientasi kepada status tertentu yang mementingkan gelar daripada kualitas manusia. Padahal, hal ini akan menghambat kreativitas serta kemampuan pribadi yang amat diperlukan dalam masa kompetitif di abad ke-21. Hal lainnya adalah tingginya sikap senioritas dan cenderung mengaburkan penilaian objektif. Sementara itu, tidak bisa dipungkiri bahwa dalam memperoleh sertifikasi dan label fair trade memerlukan biaya yang tidak sedikit. Di samping itu, persoalan "siapa mendapat apa" mengemuka di kalangan produsen. Jika mereka memandang bahwa tidak ada keuntungan dari kegiatan fair trade, maka sertifikasi dan aturan fair trade tersebut tidak akan mereka penuhi. Alih-alih mereka lebih memilih menjual produknya kepada tengkulak di pasar konvensional. Temuan ini penulis dapatkan dalam sebuah diskusi singkat dengan petani kopi yang berasal dari 
kawasan Bandung Selatan pada medio April 2018 bahwa sertifikasi fair trade menjadi sebuah pilihan kedua yakni manakala calon buyer meminta mereka mengurusi sertifikasinya.

Dalam studi lainnya dengan 228 sampel petani di Nicaragua Utara, mengatakan bahwa meskipun fair trade mampu meningkatkan kapabilitas para produsen di negara dunia ketiga, namun dampak fair trade tidak terlalu menonjol. Christopher Bacon (2005 : 497-511) mendapati bahwa tiada hubungan positif antara kualitas kopi dengan harga. Adapun yang turut mempengaruhi adalah sertifikasi organik atau fair trade dalam produk tersebut.

\section{Kesimpulan}

Persoalan fair trade dan dampaknya bagi para produsen dan petani di negara berkembang, menjadi topik yang menarik untuk dikaji. Diperlukan uraian dan penelitian yang lebih komprehensif mengenai fenomena ini. Kendati demikian, kita dapat menarik kesimpulan bahwa fair trade dapat menjadi sebuah sistem hanya jika dijalankan secara sistematis. Artinya, keberadaan negara tidak bisa kita hindarkan. Peran negara dalam menjamin kesejahteraan masyarakat menjadi tugas pokoknya. Pada beberapa kasus didapati bahwa fair trade belum menyentuh akar persoalan. Meskipun demikian tidak dapat dipungkiri bahwa manfaat fair trade begitu luas sehingga menjadi secercah harapan bagi para produsen kecil untuk memasuki pasar internasional. 
Gerakan sosial seperti ini seharusnya menjadi pemicu dan menjadi media bersinergi dalam mewujudkan cita-cita negara kesejahteraan (welfare state). Keterlibatan negara serta peran lembaga swadaya dalam membantu perekonomian masyarakat bawah menjadi faktor penentu dalam pembangunan ekonomi makro dan dapat mereduksi kesenjangan Utara-Selatan. 


\section{DAFTAR PUSTAKA}

Bacon, Christopher. "Confronting the coffee crisis: Can fair trade, organic and specialty coffees reduce small-scale farmer vulnerability in Northern Nicaragua?" World Development Vol. 33 No3. p.497-511. 2005.

Carroll, A.B. "The pyramid of corporate social responsibility: towards the moral management of organizational stakeholders", Business Horizons, Vol. 34, 1991.

Crane, George T. dan Abla Amawi (eds.) . The Theoretical Evolution of International Political Economy. Oxford: Oxford University Press, 1991.

Crump, Larry (ed), S. Javeed Maswood, Developing Countries and Global Trade Negotiataions, New York : Routledge, 2007.

Decarlo, Jacqueline. Fair Trade : A Beginner's Guide. Oxford: One World Publication, 2007.

Eaton, Kit. Apple and Foxconn's Ethic Hit Your Gadget Prices. https://www.fastcompany.com/1819874/apple-and-foxconnsethics-hit-your-gadget-prices-updated [Diakses pada $10 \mathrm{Mei}$ 2018] Hudson, Mark, Ian Hudsson, Mara Fridell. Fair Trade, Sustainability, and Social Change. Hampshire: Palgrave Macmillan, 2013.

Hoekman, Bernard, Marcelo Olarreaga (ed), Global Trade and Poor Nations, Washington DC : Brookings Institution Press.

Lynch, David. A, Trade and Globalization : An Introduction to Regional Trade Agreements, Maryland : Rowman \& Littlefield Publisher, 2010.

Lyon, Sarah. 2007. Fair trade coffee and human rights in Guatemala.Journal of Consumer Policy 30: 241-261.

Ranjabar, Jacobus, Sistem Sosial Budaya Indonesia, Ghalia Indonesia : Bogor, 2006.

Stiglitz, Joseph. E, Andrew Charlton. Fair Trade for All : How Trade Can Promote Development. Oxford : Oxford University Press, 2005. 
Suranovic, Steven M. "A Positive Analysis of Fairness with Applications to International Trade" World Economy 23(3):283-307 - February 2000.

World Fair Trade Organization. Definition of Fair Trade. https://wfto.com/fair-trade/definition-fair-trade [diakses pada 10 Mei 2018].

World Trade Organization. World Trade Statistical Review 2016. https://wto.org/statistics [diakses pada 10 Mei 2018).

Yusida, Ermita, Juwita. P.R Suwondo, "Is Fair Trade really a Solution to Create a fairness in Agricultural Trade? - Case in Indonesia". International Journal of Trade, Economics and Finance. Vol. 5 No.3 June 2014, 277-284.

Zampetti, Americo B. Fairness in The World Economy. Cheltenham : Edward Elgar, 2006 